DOI: http://dx.doi.org/10.33846/ghs5303

\title{
Formulasi Sediaan Salep Esktrak Etanol Daun Sirsak (Anonna mucirata L.) Dengan Variasi Basis Salep
}

\author{
Indian Cahyani (koresponden) \\ (Mahasiswa Program Studi Farmasi STIKes Maluku Husada; indiancahyanii@gmail.com) \\ Aulia D. Pelu \\ (Dosen STIKes Maluku Husada; auliadebbypelu@gmail.com) \\ Jayanti Djarami \\ (Dosen STIKes Maluku Husada; apotekerjayanti@gmail.com) \\ Epi Dusra \\ (Dosen STIKes Maluku Husada; dusraephy@gmail.com)
}

\begin{abstract}
The use of natural ingredients as traditional medicine with better use is now more in demand. This is because traditional medicine is relatively easy to obtain. One type of medicinal plant that is often used by the community is (Annona mucirata L). or better known as soursop. Soursop leaves (Anonna mucirata L.) have been widely used as a medicinal ingredient because it contains tannin and flavanoid compounds which can provide antibacterial effects. The purpose of this study was to determine the content of the compounds contained in soursop leaves (Anonna mucirata L.) and to formulate an ethanol extract ointment of soursop leaves (Anonna mucirata L.) with various ointment bases. This research was conducted using an experimental method in which evaluations of the ointment were carried out including the organoleptic test, $\mathrm{pH}$ test and homogeneity test. The results showed that ethanol extract of soursop leaves (Anonna mucirata L.) containing tannins and flavonoids. The results of the ointment formulation on the hydrocarbon base formulation, the absorption base formulation and the water soluble base formulation resulted in physical differences in the organoleptic test, but did not have different results on the homogeneity test and $\mathrm{pH}$ test. In conclusion, extract ethanol of soursop (Anonna mucirata L.) leaf contains tannin and flavanoid compounds. The ethanol extract ointment of soursop leaves (Anonna mucirata L.) with variations of FI (hydrocarbon base) and FII (absorption base) ointment has good ointment properties, while FIII (water-soluble base) does not have good physical properties because it has a dosage form which is liquid and smells rancid based on the organoleptic test. The ethanol extract ointment of soursop leaves (Anonna mucirata L.) with variations of FI (hydrocarbon base) and FIl (absorption base) ointment has good ointment properties, while FIII (water-soluble base) does not have good physical properties because it has a liquid dosage form and smells rancid based on the organoleptic test.
\end{abstract}

Keywords: ointment extract; soursop plant; ointment base

\section{ABSTRAK}

Pemanfaatan bahan alam sebagai obat tradisional dengan penggunaan yang lebih baik sekarang lebih diminati. Hal ini dikarenkan obat tradisional relatif mudah didapat. Salah satu jenis tanaman obat yang sering dimanfaatkan oleh masyarakat adalah (Annona mucirata L). atau yang lebih di kenal dengan nama sirsak. Tanaman daun sirsak (Anonna mucirata L.) sudah banyak digunakan sebagai bahan obat karena mengandung senyawa tannin dan flavanoid yang mampu memberikan efek antibakteri. Tujuan penelitian ini untuk mengetahui kandungan senyawa yang terdapat pada daun sirsak (Anonna mucirata L.) serta membuat formulasi sediaan salep esktrak etanol daun sirsak (Anonna mucirata L.) dengan variasi basis salep. Penelitian ini dilakukan dengan menggunakan metode experimental dimana dilakukan evaluasi terhadap salep yang dibuat meliputi uji organoleptik, uji pH dan uji homogenitas. Hasil penelitian ini yaitu ekstrak etanol daun sirsak (Anonna mucirata L.) mengandung senyawa tannin dan flavanoid, untuk hasil formulasi sediaan salep pada formulasi basis hidrokarbon, formulasi basis absorbsi dan formulasi basis larut air menghasilkan perbedaan fisik uji organoleptik, namun tidak memiliki hasil yang berbeda pada uji homogenitas dan uji $\mathrm{pH}$. Dari hasil penelitian dapat disimpulkan yaitu ekstrak estanol daun sirsak (Anonna mucirata L.) mengandung senyawa tannin dan flavanoid. Sediaan salep esktrak etanol daun sirsak (Anonna mucirata L.) dengan variasi basis salep FI (basis hidrokarbon) dan FII (basis absorbsi) memiliki sifat salep yang baik, sedangkan FIII (basis larut air) tidak memiliki sifak fisik yang baik karena memiliki bentuk sediaan yang cair dan bau tengik berdasarkan uji organoleptik.

Kata kunci: ekstrak salep; tanaman daun sirsak; basis salep 


\section{PENDAHULUAN}

Pemanfaatan bahan alam sebagai obat tradisional dengan penggunaan yang lebih baik sekarang lebih diminati. Hal dikarenakan obat tradisional relatif mudah di dapat. Di dukung dengan adanya bahan obat dari alam yang tumbuh melimpah di Indonesia, sehingga penggunaan obat tradisional menjadi semakin meningkat dan berkembang luas di masyarakat ${ }^{[3]}$.

Tanaman obat yang sering dimanfaatkan oleh masyarakat adalah Annona mucirata L. atau yang lebih di kenal dengan nama sirsak. Daun sirsak mampu mengatasi jerawat. Bakteri yang sering di temukan pada jerawat adalah Staphylococcus aureus dan Propionibacterium acnes ${ }^{[4]}$

Di Indonesia kegunaan daun sirsak sebagai obat kanker payudara dan menurunkan gula darah. Sedangkan di Maluku daun sirsak di gunakan untuk melindungi sistem kekebalan tubuh, menurunkan berat badan secara signifikan dan menormalkan kerja sistem pencernaan ${ }^{[5]}$

Tanaman sirsak (Annona mucirata L.) merupakan salah satu tanaman yang hidup di daerah tropis. Tanaman ini memiliki banyak khasiat, mulai dari daun sampai batangnya dapat di manfaatkan. Bagian yang paling istimewa dari tanaman sirsak adalah terletak pada daunnya. Selain daun sirsak, kulit kayu, akar, batang, dan ekstrak biji buah sirsak (Annona mucirata L.) juga dapat digunakan sebagai antibakteri Kandungan senyawa yang terdapat0 pada daun sirsak antara lain steroid/terpenoid, flavanoid, alkaloid, dan tannin [2]

Penelitian terdahulu yang di lakukan oleh (Ita Ilasmia. dkk, 2015) tentang efektivitas salep ekstrak daun sirsak (Annona mucirataL.)pada mencit yang terinfeks bakteri staphylococcus aureus terdapat senyawa aktif sekunder secara umum pada daun sirsak yakni alkaloid, saponin, tannin dan flavanoid selain itu ekstrak daun sirsak (Annona mucirata L.) memiliki efektivitas antibakteri terhadap bakteri Staphylacoccus aureus, dan pada pengujian efektivitas salep ekstrak daun sirsak terbukti dapat memberikan efek antibakteri terhadap infeksi Staphylacoccus aureus pada mencit dengan konsentrasi efektif $15 \%$ dan $30 \%$

Salep merupakan sediaan setengah padat yang ditujukan untuk pemakaian topikal pada kulit atau selaput lendir. Formulasi salep dibutuhkan adanya suatu basis, basis sendiri merupakan zat pembawa yang bersifat inaktif dari sediaan topikal dapat berupa bentuk cair atau padat yang membawa bahan aktif untuk berkontak dengan kulit. ${ }^{[6]}$

Pemilihan basis salep yang tepat sangat penting karena basis salep mempengaruhi efek terapeutik dari suatu salep. Salep digunakan pada epidermis, mukosa, salep penetrasi atau bentuk krim memerlukan basis salep yang berbeda-beda. Kelarutan dan stabilitas obat di dalam basis, juga sifat luka pada kulit, menentukan pilihan dari pembawa sediaan semi padat. Basis salep terbagi menjadi empat golongan, yaitu: basis hidrokarbon, basis serap, basis absorbsi, basis yang dapat cuci dengan air, dan basis yang larut dalam air ${ }^{[1]}$.

Berdasarkan latar belakang tersebut maka pada penelitian ini penulis tertarik untuk meneliti tentang pengunaan variasi basis salep yaitu basis hidrokarbon (vaselin putih 85,989\%), basis absorbsi (vaselin putih 85,989\% dan lanolin 3\%), basis larut air (PEG 400 70,38\%) Sehingga diharapkan dapat menghasilkan sediaan salep yang baik dan stabil.

Tujuan peneltian ini adalah mengetahui kandungan senyawa yang terdapat pada daun sirsak (Annona mucirata L.) serta membuat formulasi sediaan salep dari esktrak etanol daun sirsak (Annona mucirata L.)

\section{METODE}

Penelitian ini dilakukan di Laboratoirum Bahan Alam dan Laboratoirum Tehnologi Farmasi Sekolah Tinggi IImu Kesehatan Maluku Husada. Alat yang digunakan dalah kertas saring, bejana kaca, batang pengaduk, mortir, penangas air, timbangan analitik, gelas ukur, gelas kimia, cawan porselen, spatula, wadah tempat salep, $\mathrm{pH}$ universal, corong, pipet volume, pipet tetes, tabung reaksi, rak tabung. Bahan yang digunakan dalam penelitian ini adalah ekstrak daun sirsak (Annona mucirata L.), etanol 70\%, Natur-E, cera alba, metil paraben, propil paraben, vaselin album, PEG 400, lanolin anhidrat, aquades, $\mathrm{FeCl}_{3} 1 \%, \mathrm{HCL} 2 \mathrm{~N}, \mathrm{HCL}$ pekat, pereaksi drangendrof.

\section{Prosedur Penelitian}

\section{Esktraksi sampel}

Sampel yang telah di kumpulkan, di timbang dan beratnya $3 \mathrm{~kg}$ di cuci bersih dengan air mengalir, kemudian di potong kecil-kecil setelah itu di jemur dengan cara di angin-anginkan tanpa terkena sinar matahari langsung, sampel yang telah kering, kemudian di haluskan. 
Ditimbang sebanyak 500 gram, kemudian di tambahkan pelarut etanol $70 \%$ sebanyak $2700 \mathrm{ml}$ hingga serbuk terendam sempurna dan diamkan selama $2 \times 24$ jam sesekali diaduk. Setelah itu hasil rendamen di saring mengunakan kain putih hingga didapat filtrat kemudian residunya ditambahkan kemabli deng an etanol $70 \%$ sebanyak $1700 \mathrm{ml}$ dan didiamkan selama $1 \times 24$ jam sesekali diaduk, disaring menggunakan kain putih hingga di dapat filtrat kemudian digabungkan hasil filtrat tersebut dan diupakan menggunkan hay drayer hingga didapat ektrak kental daun sirsak

\section{Skrinning Fitokimia}

Identifikasi yang dilakukan dalam penelitian ini adalah identifikasi senyawa tannin, flavanoid, alkaloid, saponin dan fenol

- Uji Tannin

Sebanyak $1 \mathrm{ml}$ esktrak ditambahkan 10-15 tetes larutan $\mathrm{FeCl}_{3}$ (Besi III Klorida) $1 \%$, bila bereaksi positif akan menghasilkan warna hijau, merah, ungu, biru atau hitam

- Uji Flavonoid

Ditambahkan serbuk Mg (Magnesium) dan $2 \mathrm{ml}$ asam klorida (HCL) $2 \mathrm{~N}$ pada $2 \mathrm{ml}$ larutan esktrak. Senyawa flavanoid akan menunjukkan warna jingga atau merah

- Uji Alkaloid

Dilakukan dengan cara memasukkan $1 \mathrm{ml}$ ekstrak kedalam tabung reaksi ditambahkan $2 \mathrm{ml}$ asam klorida (HCL) kemudian ditambahkan $1 \mathrm{ml}$ pereaksi dragendrof hasil positif adanya alkaloid ditunjukan dengan terbentuknya endapan jingga

- Uji Saponin

Ekstrak sampel sebanyak $1 \mathrm{ml}$ dimasukkan kedalam tabung reaksi, lalu ditambahkan $10 \mathrm{ml}$ aquades panas, setelah itu didinginkan dan dikocok secara kuat selama 10 menit sehingga terbentuk buih dan tidak hilang selama 10 menit kemudian ditambahkan 1 tetes asam klorida (HCL) $2 \mathrm{~N}$ jika buih tidak hilang menunjukkan adanya saponin

- Uji Fenol

Dimasukkan $1 \mathrm{ml}$ esktrak ke dalam tabung reaksi lalu ditambahkan beberapa tetes air panas dan pereaksi besi III klorida $1 \%$ terjadinya perubahan warna larutan menjadi warna hijau, biru atau ungu menunjukkan adanya fenol

Tabel 1. Formulasi Salep Ekstrak Daun Sirsak (Annona mucirata L.)

\begin{tabular}{|c|c|c|c|c|}
\hline \multirow[b]{2}{*}{ Bahan } & \multicolumn{3}{|c|}{ Konsentrasi (\%) } & \multirow[b]{2}{*}{ Kegunaan } \\
\hline & $\begin{array}{l}\text { Formulasi I } \\
\text { (Basis } \\
\text { hidrokarbon) }\end{array}$ & $\begin{array}{l}\text { Formulasi II } \\
\text { (Basis } \\
\text { absorbsi) }\end{array}$ & $\begin{array}{l}\text { Formulasi III } \\
\text { (Basis larut } \\
\text { air) }\end{array}$ & \\
\hline $\begin{array}{l}\text { Ekstrak daun sirsak } \\
\text { (Anonna mucirata L.) }\end{array}$ & 20 & 20 & 20 & Zat aktif \\
\hline Cera alba & 5 & 5 & & Pemadar \\
\hline Metil paraben & & & 0,02 & Pengawet \\
\hline Propil paraben & 0,01 & 0,01 & & Pengawet \\
\hline PEG 400 & & & 70,38 & Basis \\
\hline Vaselin putih & $85,989 \%$ & $85,989 \%$ & & Basis \\
\hline Lanolin & & $3 \%$ & & Basis \\
\hline Natur-e & qs & Qs & qs & Antioksidan \\
\hline Jumlah bahan & 110,999 & 113,999 & 98,58 & \\
\hline
\end{tabular}

\section{Pembuatan Sediaan Salep}

\section{Salep Hidrokarbon}

Cera alba dan vaselin album ditimbang sesuai dengan perhitungan, dimasukkan ke cawan porselen kemudian dilebur dalam penangas air. Basis yang telah meleleh di aduk hingga homogen dalam mortir, setelah tercampur kemudian ditambahkan propil paraben dan Natur-E secukupnya diaduk hingga homogen dalam mortir, ditambahkan esktrak daun sirsak sedikit demi sedikit, lalu diaduk hingga homogen. 


\section{Salep Basis Absorbsi}

Cera alba dan vaselin album ditimbang sesuai dengan perhitungan, dimasukkan ke cawan porselen kemudian dilebur dalam panangas air. Basis yang telah meleleh diaduk hingga homogen dalam mortir, ditambahkan lanolin anhidrat, dan diaduk hingga semua bahan tercampur homogen, kemudian ditambah propil paraben dan Natur-E secukupnya diaduk hingga homogen dalam mortir dan ekstrak daun sirsak ditambahkan sedikit demi sedikit, lalu di aduk hingga homogen.

\section{Salep Basis Larut Air}

PEG 400 ditimbang sesuai dengan perhitungan diaduk hingga homogen dalam mortir, kemudian ditambahkan metil paraben dan Natur-E sesuai dengan perhitungan dan diaduk hingga homogen. Ekstrak daun sirsak di tambahkan sedikit demi sedikit, lalu diaduk hingga homogen.

\section{Uji Stabilitas Salep}

Uji organoleptik

Pengujian organoleptik dilakukan dengan mengamati sediaan salep dari bentuk, bau, dan warna sediaan.

$\underline{\text { Uji homogenitas }}$

Pengujian homogenitas dilakukan dengan mengoleskan 0,1 gram salep pada permukaan gelas objek, sediaan salep dikatakan homogen apabila tidak terdapat butiran kasar pada gelas objek. (Voight, 1984)

$\underline{\text { Uji pH}}$

Pengukuran $\mathrm{pH}$ salep dilakukan dengan menggunakan alat $\mathrm{pH}$ - meter. Sebanyak 0,5 gram salep ekstrak etanol daun sirsak dilarutkan dalam $50 \mathrm{ml}$ air suling didalam gelas beker

HASIL

\section{Hasil Skrinning Fitokimia Ekstrak Etanol Daun Sirsak}

Penelitian ini menggunkan sampel daun sirsak (Anonna mucirata L.) sebanyak $500 \mathrm{gr}$ dengan $2 x$ penyaringan, kemudian diekstraksi dan diuapkan hingga mendapatkan esktrak kental yang digunakan untuk uji skrinning fitokimia dengan menambahkan beberapa reagen atau pereaksi warna. Hasil uji skrinning fitokimia esktrak etanol daun sirsak (Anonna mucirata L.) mengandung senyawa tannin dan flavanoid.

Tabel 1. Hasil Uji Skrinning Fitokimia

\begin{tabular}{|c|l|c|l|}
\hline Pemeriksaan & \multicolumn{1}{|c|}{ Perlakuan } & Hasil & \multicolumn{1}{|c|}{ Keterangan } \\
\hline Tannin & Esktrak $+\mathrm{FeCl}_{3} 1 \% 10-15$ tetes & + & Terbentuk warna hitam \\
\hline Flavanoid & Esktrak + serbuk $\mathrm{Mg}+\mathrm{HCL} \mathrm{2N}$ & + & Terbentuk warna jingga \\
\hline Alkaloid & Ekstrak $+\mathrm{HCL}+$ Perekasi dragendrof & - & Tidak terbentuk endapan jingga \\
\hline Saponin & Ekstrak + aquades panas $+\mathrm{HCL} \mathrm{2} \mathrm{N}$ & - & Tidak terbentuk buih \\
\hline Fenol & Esktrak + aquades panas $+\mathrm{FeCl}{ }_{3} 1 \%$ & - & Tidak terbentuk warna hijau atau biru \\
\hline
\end{tabular}

Keterangan: (+): Teridentifikasi senyawa (-): Tidak teridentifikasi senyawa

\section{Hasil Evaluasi Fisik Sediaan Salep Esktrak Etanol Daun Sirsak}

\section{Uji Organoleptik}

Uji organoleptik bertujuan unuk melihat sifat fisik sediaan salep yang meliputi bentuk, bau dan warna selama proses penyimpanan satu minggu. hasil uji organoleptik sediaan salep esktrak etanol daun sirsak (Anonna mucirata L.), pada formulasi I dan formulasi II memiliki bentuk, bau dan warna 
yang sama selama proses penyimpanan 1 minggu, sedangkan formulasi III memiliki bentuk yang cair, bau tengik dan berwarna hijau.

Tabel 2. Hasil uji organoleptik

\begin{tabular}{|c|c|c|}
\hline \multirow{2}{*}{ Formulasi } & \multicolumn{2}{|c|}{ Pengamatan } \\
\cline { 2 - 3 } & Sebelum penyimpanan & Setelah penyimpanan \\
\cline { 2 - 3 } & Bentuk & Bentuk \\
\hline FI & Setengah padat & Setengah padat \\
\hline FII & Setengah padat & Setengah padat \\
\hline \multirow{2}{*}{ FIII } & \multicolumn{2}{|c|}{ Pengamatan } \\
\hline \multirow{2}{*}{ Cormulasi } & Sebelum penyimpanan \\
\cline { 2 - 3 } & Bau & Setelah penyimpanan \\
\cline { 2 - 3 } & $\begin{array}{c}\text { Aroma esktrak daun } \\
\text { sirsak }\end{array}$ & $\begin{array}{c}\text { Aroma esktrak daun } \\
\text { sirsak }\end{array}$ \\
\hline \multirow{2}{*}{ FII } & $\begin{array}{c}\text { Aroma esktrak daun } \\
\text { sirsak }\end{array}$ & $\begin{array}{c}\text { Aroma esktrak daun } \\
\text { sirsak }\end{array}$ \\
\hline \multirow{2}{*}{ FIII } & Tengik & Tengik \\
\hline \multirow{2}{*}{ Formulasi } & Pengamatan \\
\cline { 2 - 3 } & Sebelum penyimpanan & Setelah penyimpanan \\
\cline { 2 - 3 } & Warna & Warna \\
\hline FI & Hijau kehitaman & Hijau kehitaman \\
\hline FII & Hijau kehitaman & Hijau kehitaman \\
\hline FIII & Cair & Cair \\
\hline
\end{tabular}

$\underline{\text { Uji Homogenitas }}$

Uji homogenitas bertujuan untuk melihat apakah bahan-bahan dari sediaan salep tercampur menjadi homogen atau tidak. Hasil uji homogenitas sediaan salep eskrak etanol daun sirsak (Anonna mucirata L.) dari ketiga formulasi memiliki hasil yang homogen selama proses penyimpanan 1 minggu

Tabel 3. Hasil uji homogenitas

\begin{tabular}{|c|c|c|}
\hline \multirow{2}{*}{ Formulasi } & \multicolumn{2}{|c|}{ Homogenitas } \\
\cline { 2 - 3 } & Sebelum penyimpanan & Setelah penyimpanan \\
\hline FI & Homogen & Homogen \\
\hline FII & Homogen & Homogen \\
\hline FIII & Homogen & Homogen \\
\hline
\end{tabular}

$\underline{\text { Uji pH}}$

Uji pH bertujuan untuk melihat tingkat keasaman dan kebasaan pada sediaan salep esktrak etanol daun sirsak untuk menjamin sediaan salep tidak menyebabkan iritasi pada kulit. hasil uji pH sediaan salep esktrak etanol daun sirsak (Anonna mucirata L.), pada formulasi I, II dan III sebelum peyimpanan memiliki nilai $\mathrm{pH} 5$ dan setelah penyimpanan selama 1 minggu nilai $\mathrm{pH}$ menurun menjadi 4.

Tabel 4. Hasil uji pH

\begin{tabular}{|c|c|c|}
\hline \multirow{2}{*}{ Formulasi } & \multicolumn{2}{|c|}{$\mathrm{pH}$} \\
\cline { 2 - 3 } & Sebelum penyimpanan & Setelah penympanan \\
\hline FI & 5 & 4 \\
\hline FII & 5 & 4 \\
\hline FIII & 5 & 4 \\
\hline
\end{tabular}




\section{PEMBAHASAN}

\section{Uji Skrinning Fitokimia}

$\underline{\text { Uji Tannin }}$

Hasil uji tannin ekstrak etanol daun sirsak (Anonna mucirata L.) menunjukkan hasil positif atau mengandung senyawa tannin yang ditandai dengan berwarna hitam. Hal ini dikarenakan adanya penambahan $\mathrm{FeCl}_{3}$ untuk menentukan apakah sampel mengandung gugus fenol atau tidak, adanya gugus fenol dintunjukkan dengan warna hitam atau biru tua

\section{$\underline{\text { Uji Flavanoid }}$}

Hasill uji flavanoid eksrak etanol daun sirsak (Anonna mcuirata L.) menunjukkan hasil positif atau mengandung senyawa flavanoid yang ditandai dengan warna jingga, hal ini dikarenakan adanya penambahan serbuk $\mathrm{Mg}$ dan $\mathrm{HCL} 2 \mathrm{~N}$ untuk mereduksi inti benzopiron yang terdapat dalam struktur flavanoid senhingga terbentuk garam flaviliun berwarna merah atau jingga

\section{$\underline{\text { Uji Alkaloid }}$}

Untuk uji alkaloid esktrak etanol daun sirsak (Anonna mucirata L.) menunjukkan hasil negatif yang tidak terbentuknya endapan jingga, hal ini dikarenakan adanya perbedaan unsur hara atau tanah, penelitian ini tidak sejalan dengan penelitian yang dilakukan oleh Herwandi dkk, 2019 hasil uji skrinning fiokimia esktrak etanol daun sirsak (Anonna mcuirata L.) dinyatakan positif atau mengandung senyawa alkaloid

\section{$\underline{\text { Uji Saponin }}$}

Uji saponin eskrtak etanol daun sirsak (Anonna mucirata L.) menujukkan hasil negatif yang tidak terbentuknya buih, hal ini dikarenakan adanya perbedaan unsur hara atau tanah, penelitian ini tidak sejalan dengan penelitian yang dilakukan oleh Herwandi dkk, 2019 hasil uji skrinning fitokimia ekstrak etanol daun sirsak (Anonna mucirata L.) dinyatakan positif atau mengandung senyawa saponin

\section{$\underline{\text { Uji Fenol }}$}

Uji fenol esktrak etanol daun sirsak (Anonna mucirata L.) menunjukkan hasil negatif yang tidak terbentuk warna hijau, biru atau ungu, hal ini dikarenakan adanya perebedaan unsur hara atau tanah, penelitian ini tidak sejalan dengan penelitian yang dilakukan oleh Herwandi dkk, 2019 hasil uji skrinning fitokimia ekstrak etanol daun sirsak (Anonna mucirata L.) dinyatakan positif atau mengandung senyawa fenol

\section{Evaluasi Sediaan Salep Ekstrak Etanol Daun Sirsak}

\section{Uji Organoleptik}

Bersadasarkan hasil uji organoleptik sediaan salep esktrak etanol daun sirsak (Anonna mucirata L.), pada FI (Basis Hidrokarbon) dan FII (Basis Absorbsi) memiliki bentuk yang setengah padat, kemudian warna dari kedua formulasi menghasilkan warna hijau kehitaman dan berbau aroma esktrak daun sirsak. Hal tersebut menjukkan kedua salep dapat memenuhi syarat atau stabil yang berbentuk setengah padat dan tidak berbau tengik. Untuk FIII (Basis Larut Air) menghasilkan bentuk yang cair, hal ini disebabkan karena bentuk sediaan dari PEG 4000 berupa serbuk sehingga banyaknya penambahan bahan ini akan semakin mengentalkan sediaan, begitu pun sebaliknya ketika sediaan yang memiliki konsentrasi PEG 4000 lebih sedikit dari PEG 400 yang lebih banyak memiliki sifat kurang kental, kemudian menghasilkan warna yang hijau, dan bau yang tengik hal ini dikarenakan sediaan salep banyak mengandung air sehingga terjadi kelembapan.

\section{Uji Homogenitas}

Bersadasarkan hasil uji homogenitas esktrak etanol daun sirsak (Anonna mucirata L.) dari ketiga formulasi menunjukkan hasil yang homogen atau tidak terdapat butiran kasar pada objek glas selama proses penyimpanan satu minggu 
$\underline{\text { Uji pH}}$

Berdasarkan hasil uji pH sediaan salep esktrak etanol daun sirsak (Anonna mucirata L.) sebelum penyimpanan dari ketiga formulasi memiliki nilai $\mathrm{pH}$ yaitu 5 dan setelah penyimpanan terjadi perubahan nilai $\mathrm{pH}$ dari ketiga formulasi yaitu 4. Hal ini disebabkan karena adanya faktor suhu (temperatur) dan kondisi ruangan sehingga terjadinya penurunan atau perubahan nilai $\mathrm{pH}$ pada sediaan. Suhu yang baik selama proses peyimpanan yaitu $40^{\circ} \mathrm{C}$. Namun hal tersebut dinyatakan nilai $\mathrm{pH}$ pada sediaan salep stabil karena nilai $\mathrm{pH}$ yang baik pada kulit adalah $4,5-6,5$

\section{KESIMPULAN}

Dari hasil penelitian dapat disimpulkan bahwa:

1. Ekstrak estanol daun sirsak (Anonna mucirata L.) mengandung senyawa tannin dan flavanoid

2. Sediaan salep esktrak etanol daun sirsak (Anonna mucirata L.) dengan variasi basis salep FI (basis hidrokarbon) dan FII (basis absorbsi) memiliki sifat salep yang baik, sedangkan FIII (basis larut air) tidak memiliki sifak fisik yang baik karena memiliki bentuk sediaan yang cair dan bau tengik berdasarkan uji organoleptik.

\section{DAFTAR PUSTAKA}

1. Ansel, H C. Pengantar Bentuk Sediaan Farmasi. Edisi IV. Jakarta: UI Press, 1989.

2. Febriani, D., Mulyanti, D., \& Rismawati, E. Karakterisasi Simplisia dan Ekstrak Etanol Daun Sirsak 2015 (pp.475-480)

3. Ita Ilasmila, Amaliah, \& Muhammad Danial. Efektivitas Salep Ekstrak Daun Sirsak (Annona mucirata L.) Pada Mencit Yang Terinfeksi Bakteri Staphylococcus aureus. 2015.

4. Jawetz, E., Melnick, J.L., \& Adelbreg, E.A., Mikrobiologi Kedokteran Edisi XXII. diterjemahkan oleh Bagian Mikrobiologi Fakultas Kedokteran Universitas Airlangga, Salmeba Medika: Jakarta. 2001

5. Muhartono, Subeki. Penggunaan Ekstrak Daun Sirsak Sebagai Obat Kemoterapi Kanker Payudara. 2015.

6. Rita Novita, Mutiara \& Rima Hayati. Formulasi Sediaan Salep Ekstrak Etanol Pliek U Sebagai Antibakteri. 2000. 